\title{
Evaluation of patient perceptions and outcomes related to anticoagulation point-of-care testing in ambulatory care clinics
}

\author{
Amy N. THOMPSON, Kelly R. RAGUCCI, Joli D. FERMO, Heather P. WHITLEY.
} Received (first version): 10-Jul-2009 Accepted: 3-Oct-2009

\begin{abstract}
${ }^{*}$
Until recently, Prothrombin Time/International Normalized Ratio (PT/INR) measurements have typically been used to monitor patients on warfarin through institutional laboratories via venous puncture. The Point-of-Care Testing (POCT) device has revolutionized the patient care process by allowing for laboratory testing outside of the central laboratory.

Objective: To analyze humanistic and clinical outcomes in patients currently treated with warfarin and monitored through a pharmacist-managed anticoagulation clinic using point-of-care testing (POCT) device versus venipuncture within ambulatory care clinics at our institution.

Methods: All patients currently treated with warfarin therapy who were managed by clinical pharmacists for anticoagulation monitoring at the Medical University of South Carolina (MUSC) Family Medicine Center and University Diagnostic Center, were enrolled. Patients were asked to complete a satisfaction survey regarding their anticoagulation monitoring. In addition, data related to emergency department (ED) visits, hospitalizations and percent of time in the INR therapeutic range for 6 months pre- and post-implementation of POCT device was collected. This information was obtained through an electronic patient information database, Oacis. Results: A total of 145 patients were included in the data collection from the two clinics. The majority $(41 \%)$ of these patients were taking warfarin for atrial fibrillation. Satisfaction surveys were completed by 86 (59\%) of patients. The surveys revealed that POCT device was preferred over venipuncture in $95 \%$ of patients. Reasons for the preference included more face-to-face interaction, less wait time, less pain, less blood needed, and quicker results. Of the 145 patients who were
\end{abstract}

*Amy N. THOMPSON. PharmD, BCPS. Primary Care with Emphasis in Family Medicine Resident. Medical University of South Carolina. Charleston, SC (United States). Kelly R. RAGUCCI. PharmD, FCCP, BCPS, CDE. Associate Professor, Pharmacy and Clinical Sciences/Family Medicine. South Carolina College of Pharmacy, Medical University of South Carolina Campus. Charleston, SC (United States)

Joli D. FERMO. PharmD, BCPS, BC-ADM. Consultant

Pharmacist. Fermo Psychiatric Solutions. Mount Pleasant, SC (United States)

Heather P. WHITLEY. PharmD, BCPS, CDE. Clinical

Assistant Professor. Auburn University Harrison School of Pharmacy, Department of Pharmacy Practice and The University of Alabama School of Medicine, Tuscaloosa, Department of Community and Rural Medicine. Tuscaloosa, AL (United States). included in the objective data analysis, no significant differences were found in the number of hospitalizations, ED visits, or percent of time in the INR therapeutic range pre- and postimplementation of POCT device. Conclusion: The results of this study demonstrate improvement in patient satisfaction with POCT compared to venipuncture, with limited value in clinical outcomes.

Keywords: Point-of-Care Systems. Patient Satisfaction. Pharmaceutical Services. United States.

\section{EVALUACIÓN DE LAS PERCEPCIONES Y LOS RESULTADOS DE LOS PACIENTES RELACIONADOS CON LA MONITORIZACIÓN RÁPIDA EN CLÍNICAS AMBULATORIAS}

\section{RESUMEN}

Hasta hace poco, las mediciones del tiempo de protombina/Ratio normalizado internacional (TP/RIN) se utilizaban típicamente para monitorizar pacientes con warfarina mediante laboratorios institucionales vía extracción venosa. Los aparatos de test en punto de atención (POCT) han revolucionados los procesos de cuidados de los pacientes permitiendo los análisis fuera del laboratorio central.

Objetivo: Analizar los resultados humanísticos y clínicos en pacientes actualmente tratados con warfarina y monitorizados en una clínica de anticoagulación que usa aparatos de test en punto de atención (POCT) contra la venopunción en clínicas ambulatorias en nuestra institución. Métodos: Se incluyó a todos los pacientes tratados con warfarina que eran seguidos por farmacéuticos para monitorización de la anticoagulación en Centro de Medicina Familiar y en el Centro de Diagnóstico Universitario de la Universidad Médica de Carolina del Sur (MUSC). Se pidió a los pacientes que rellenasen un cuestionario de satisfacción relativo a su monitorización de anticoagulación. Además, se recogieron los datos relativos a las visitas a urgencias, hospitalizaciones y porcentaje de tiempo con RIN en margen terapéutico durante los 6 meses pre- y postimplantación del aparato POCT. Esta información se obtuvo a través de la base de datos electrónica de información de pacientes, Oacis.

Resultados: Se recogió información de un total de 145 pacientes entre las dos clínicas. La mayoría 
(45\%) de estos pacientes utilizaban la warfarina para fibrilación auricular. Los cuestionarios de satisfacción fueron completados por $86(59 \%)$ pacientes. Los cuestionarios revelaron que el aparato de POCT era preferido sobre la venopunción por el $95 \%$ de os pacientes. Los motivos de preferencia incluyeron una interacción más personalizada, menor tiempo de espera, menos dolor, menos sangre requerida, y resultados más rápidos. De los 145 pacientes incluidos en el análisis de datos objetivos, no hubo diferencias significativas en el número de hospitalizaciones, visitas a urgencias, ni porcentaje de tiempo en el margen terapéutico de RIN pre- y postimplantación del aparato de POCT.

Conclusión: Los resultados de este estudio demuestran un incremento en la satisfacción del paciente con el POCT comparado con la venopunción, con una escasa influencia en los resultados clínicos.

Palabras clave: Sistemas de análisis rápidos. Satisfacción del paciente. Servicios farmacéuticos. Estados Unidos.

\section{INTRODUCTION}

Due to its narrow therapeutic index, risk of lifethreatening adverse effects, and numerous drugdrug, drug-food, and drug-disease interactions, warfarin therapy requires close and careful monitoring. Prothrombin Time/International Normalized Ratio (PT/INR) measurements have traditionally been monitored through institutional laboratories via venipuncture. Point-of-Care Testing (POCT) devices have revolutionized the patient care process by allowing for laboratory testing outside of the central laboratory. The portability of the POCT device has facilitated INR testing that may be performed in various settings including nursing homes, at the patient's bedside, and in ambulatory care clinics. Although various recent studies have addressed the accuracy of these devices compared to traditional laboratory testing, there has been no published data available evaluating both humanistic and clinical outcomes in pharmacist-managed clinics. ${ }^{1-7}$ At the Medical University of South Carolina (MUSC), there are three pharmacist-managed anticoagulation clinics where POCT device is utilized. Prior to the implementation of the POCT device in these clinics, warfarin management was an extremely time consuming process for both the patient and the practitioner. Patients would go to the laboratory for venipuncture and the practitioner would await the results, review the patient chart/current regimen, contact the patient via telephone with the results and finally make necessary adjustments. The turnaround time from venipuncture to receiving results was 5 hours on average. Point-of-care testing, on the other hand, altered our practice model in such a way that telephone contacts became unnecessary and the process became more streamlined. Patients arrive for their appointment with the clinical pharmacist and receive point-of-care testing followed by education and management of warfarin at the time of the visit. Follow-up appointments are made as well (2 weeks if results are not in range; 4 weeks if results are in range) and the patients are given reminder cards with new dosing instructions attached. It should be noted that the average time spent in clinic is 20-30 minutes for patients, regardless of the method utilized. The purpose of this project was to analyze humanistic and clinical outcomes in patients currently treated with warfarin and monitored through a pharmacist-managed anticoagulation clinic using the POCT device at our institution.

\section{METHODS}

All patients treated with warfarin therapy and managed by clinical pharmacists for anticoagulation monitoring at the MUSC Family Medicine Center (FMC), and at the MUSC University Diagnostic Center (UDC) were enrolled in the study. The study was conducted for one year post-implementation of the POCT device and approved by the Institutional Review Board (IRB) at MUSC. It should be noted that these two clinics were similar with regard to patient populations and type of services provided. Patients $\leq 18$ years of age and patients who refused care with the POCT system were excluded from data collection. The number of hospitalizations and ED visits and the percent of time in the INR therapeutic range for 6 months pre- and postimplementation of the POCT device, was collected on each patient through a retrospective chart review. Percent of time in the INR therapeutic range was determined by taking the total number of INRs in range during the 6 month time period and divided by the total number of INRs obtained during that time period. It should be noted that only those ED visits and hospitalizations related to a major/minor bleed or thromboembolism were recorded. Major bleeds were defined as those considered lifethreatening (intracranial or retroperitoneal) or those requiring a blood transfusion. Minor bleeds were those reported but not requiring additional testing or intervention. Data was collected via an electronic patient information database, Oacis. Currently installed in over 100 health care delivery facilities in the United States, Canada and Australia, it is the primary source for our laboratory data as well as inpatient medications, microbiology, pathology and radiology data. Oacis enables the user to create a comprehensive and unified patient record from multiple sources such as ancillary systems or other electronic medical records, and bridge the gap between inpatient and outpatient systems. A twotailed Fisher's exact test was utilized to determine statistical significance of hospital admissions, ED visits and percent of time within INR range prior and post POCT implementation. Each patient was also asked to complete a survey to assess patient satisfaction with the POCT device during an on-site visit. This survey was given to patients once they had at least two consecutive months of POCT. 


\section{RESULTS}

All 180 clinic patients were evaluated for our study, of which 145 were included in the final data analysis evaluating objective data. Thirty five patients refused to try POCT from the beginning and could not be included. Satisfaction surveys were completed by $86(59 \%)$ of the patients.

The majority of patients were female $(65 \%)$ and the average age at enrollment was 65 (range 23-92). Approximately $50 \%$ of patients enrolled were Caucasian and $50 \%$ African American (Table 1). The mean time patients were on warfarin therapy was 59 months (range 6-276 months) and $92 \%$ of patients were currently stabilized on the medication (two consecutive months within therapeutic range). Of the 86 patients completing patient satisfaction survey, $82(95 \%)$ preferred the POCT device to venipuncture. One patient $(1 \%)$ patient preferred venipuncture, stating that pain from the finger prick was more uncomfortable than venipuncture, and 3 (4\%) did not respond to this question. When looking at indications for warfarin reported from the patient satisfaction surveys and verified within Oacis, 36 $(41 \%)$ of the patients, were using warfarin therapy for atrial fibrillation. Other indications included deep venous thrombosis $(21 \%)$, pulmonary embolism $(12 \%)$, valve replacement $(7 \%)$ and other $(14 \%)$. These other indications included antiphospholipid antibody, cancer, pulmonary hypertension, and protein $\mathrm{C}$ and $\mathrm{S}$ deficiency. A total of $4(5 \%)$ patients did not know their indication for warfarin therapy on the survey.

\begin{tabular}{|c|c|}
\hline $\begin{array}{rr}\text { Gender: number (\%) } & \begin{array}{r}\text { Male } \\
\text { Female }\end{array} \\
\end{array}$ & $\begin{array}{l}51(35 \%) \\
94(65 \%)\end{array}$ \\
\hline $\begin{array}{l}\text { Age (in years): Average (range, } \\
\text { SD) }\end{array}$ & $65(23-92,15)$ \\
\hline $\begin{array}{r}\text { Race: Number (\%) } \\
\text { Caucasian } \\
\text { African American } \\
\text { Hispanic } \\
\end{array}$ & $\begin{array}{c}72(49.7 \%) \\
72(49.7 \%) \\
1(0.6 \%) \\
\end{array}$ \\
\hline $\begin{array}{ll}\text { Therapeutic INR Range } & \\
& 1.5-2.0 \\
2.0-3.0 \\
2.5-3.5\end{array}$ & $\begin{array}{c}2(1.3 \%) \\
118(81.3 \%) \\
25(17.4 \%)\end{array}$ \\
\hline
\end{tabular}

Of the patients who preferred the POCT device to venipuncture, the fact that results were obtained more quickly was most important to our patients, with a mean likert score of 4.5 (1 - least important; 5 - most important). Other common reasons for preferring the POCT device over venipuncture included less wait time, less pain, written dosing schedule provided, less blood needed and face-toface interaction with the practitioner (Figure 1). A total of $76(88 \%)$ patients surveyed stated they would recommend the POCT device to others for PT/INR monitoring. Patients reporting that they would not recommend the POCT device to others gave no explanation for this selection.

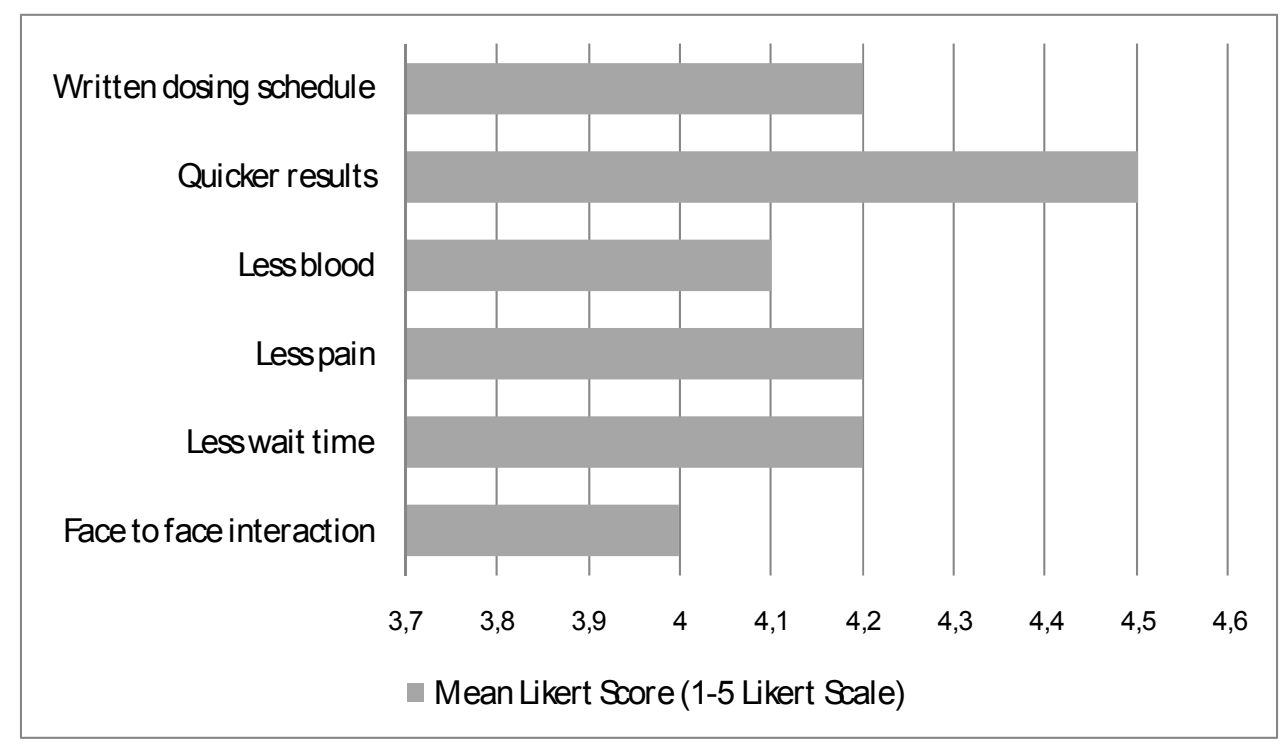

Figure 1. Reasons Patients Preferred the POCT Device

\begin{tabular}{|c|c|c|}
\hline Table 2. Objective Data \\
\hline $\begin{array}{r}\text { Hospital Admissions } \\
\text { Prior to POCT implementation } \\
\text { Post POCT implementation }\end{array}$ & $\begin{array}{c}7(4.8 \%) \\
10(6.9 \%)\end{array}$ & $\mathrm{p}=0.6184$ \\
\hline ED Visits & $3(2.1 \%)$ & $\mathrm{p}=0.7227$ \\
Prior to POCT implementation & & \\
Post POCT implementation & $5(3.4 \%)$ & \\
\hline Percentage of Time within INR Therapeutic Range & $47.9 \%$ & $\mathrm{p}=0.8874$ \\
Prior to POCT implementation & $45.7 \%$ & \\
Post POCT implementation & & \\
\hline
\end{tabular}


Although the study was not designed to evaluate gender or ethnic differences with regard to survey results, none were seen. There was no significant difference seen in other objective data collected including hospitalizations $(p=0.618)$, ED visits $(p=0.722)$, and percentage of time within the INR therapeutic range $(p=0.887)$ pre- and postimplementation of the POCT device in our clinics (Table 2). It should be noted that adherence to appointments did not differ pre- and postimplementation of POCT.

\section{DISCUSSION}

Limited published data exist regarding humanistic outcomes with anticoagulation POCT in pharmacist run anticoagulation clinics. ${ }^{1,2}$ Yamreudeewong and colleagues conducted a study with 32 patients, the primary objective was to evaluate the accuracy of the POCT device, Coumatrak, and to demonstrate the effects of pharmacist intervention on managing patients receiving warfarin therapy. ${ }^{1}$ Patients were asked to complete a questionnaire about their preference of monitoring method. The questionnaire focused on convenience, pain/discomfort, and the patient's feeling about the accuracy of the POCT device. Of the patients surveyed, $25(78 \%)$ reported that they preferred the POCT device over venipuncture. Chapman and colleagues conducted a similar study, 45 patients, evaluating the accuracy, clinical correlation, ease of use, and patient acceptance of two separate POCT devices, CoaguChek and the ProTime Microcoagulation System. ${ }^{2}$ As with our study, the majority of patients surveyed, 35 (77.8\%), preferred the POCT device to venipuncture. Similar reasons for preferring the POCT device over venipuncture were stated in Chapman's study; less pain, less difficulty obtaining blood, less anticipated time needed for clinic visit. Forty-one patients (91\%) stated they would recommend the POCT device to others. A study performed by Gardiner and colleagues conducted a prospective study to evaluate the accuracy and acceptability of patient self-with the CoaguChek $S$ device. 6 A total of 84 patients were randomized to weekly self monitoring or weekly laboratory monitoring via venipuncture for a 4 week period. There was no difference found between INRs and the majority of patients, $77 \%$, stated they preferred the self monitoring with the POCT device over commuting to the clinic for INR monitoring. Although this study involved self-monitoring rather than testing in a clinic setting, it again emphasizes the preference of POCT to traditional venipuncture. To our knowledge there is no published literature that looked at hospital admissions and ED visits both pre- and post- implementation of the POCT device for INR monitoring. Although there were slightly higher numbers of patients with hospitalizations and ED visits after implementation of POCT, it was not a large difference and we theorize that clinical pharmacists were likely more aggressive with monitoring and education at that time, as these tasks were completed one-on-one.
Subsequently, patients were more likely to be aware of potential side effects/problems and be seen in the clinic or ED for complaints. There are numerous studies looking more specifically at the accuracy of POCT devices compared to laboratory measurements of INR, as with our study, showed no difference between the INR values obtained. ${ }^{1-}$ 6,8,9 Extensive correlation studies, between the iSTAT and central laboratory, were performed at our institution by laboratory personnel to ensure the accuracy i-STAT prior to this study. Results of these studies showed no significant variation in INR between the 2 methods allowing for the routine use of the POCT devices in our clinics.

While larger than most of the currently published literature, a future study evaluating all the patients followed in our pharmacist run clinics would supply much larger numbers. A potential limitation included the use of a non-validated survey, with a potential bias toward POCT testing with the Likert scales. We feel that our study is unique in the fact that it evaluates both humanistic and objective outcomes for patients utilizing POCT compared to traditional venipuncture. In fact, we decided specifically to evaluate patient oriented evidence such as ED visits and hospitalizations, rather than simply percent of time in INR therapeutic range. Although we had fewer patients respond to the survey than originally anticipated, our numbers are larger than the other limited published data evaluating humanistic outcomes or percent of time in INR therapeutic range.

Based upon the results of this analysis, we are planning to continue POCT in our outpatient clinics and would encourage use of such testing in other pharmacist-run ambulatory care clinics around the country. It is clear that in our clinics patients indeed prefer one-on-one interaction and immediate feedback. Further determination of objective outcomes and cost analysis may be warranted.

\section{CONCLUSIONS}

Prior to this study, the use of the POCT device had not previously been studied in our clinics, and there is limited published data available evaluating both humanistic and clinical outcomes with the POCT device in pharmacist-run clinics. The great majority $(95 \%)$ of patients prefer POCT to venipuncture for INR monitoring at our institution. No significant difference was found between POCT and venipuncture with regard to hospitalizations, ED visits or percentage of time within the INR therapeutic range.

\section{CONFLICT OF INTEREST}

None of the above mentioned authors have any conflict of interest to disclose with regards to this research project. 


\section{References}

1. Yamreudeewong W, Johnson JV, Cassidy TG, Berg JT. Comparison of two methods for INR determination in a pharmacist-based oral anticoagulation clinic. Pharmacotherapy. 1996;16:1159-1165.

2. Chapman DC, Stephens MA, Hamann GL, Bailey LE, Dorko CS. Accuracy, clinical correlation and patient acceptance of two handheld prothrombin time monitoring devices in the ambulatory setting. Ann Pharmacother. 1999;33(7-8):775-780. DOI 10.1345/aph.18317

3. Pierce MT, Crain L, Smith J, Mehta V. Point-of-care versus laboratory measurement of the internationalized normalized ration. Am J Health-Syst Pharm. 2000;57(24):2271-2274.

4. Rigelsky JM, Choe HM, Curtis DM, Brosnan MJ, Mitrovich S, Streetman DS. Accuracy of the AvoSure PT Pro System compared with a hospital laboratory standard. Ann Pharmacother. 2002;36(3):380-385. DOI 10.1345/aph.1A253

5. Lizotte A, Quessy I, Vanier MC, Martineau J, Caron S, Darveau M, Dubé A, Gilbert E, Blais N, Lalonde L. Reliability, validity and ease of use of portable point-of-care coagulation device in a pharmacist-managed anticoagulation clinc. J Thromb Thrombolysis. 2002;14(3):247-254.

6. Gardiner C, Williams K, Mackie IJ, Machin SJ, Cohen H. Patient self-testing is a reliable and acceptable alternative to laboratory INR monitoring. Br J Haematol. 2005;128(2):242-247.

7. Sunderji R, Gin K, Shalansky K, Carter C, Chambers K, Davies C, Schwartz L, Fung A. Clinical impact of point-of-care vs laboratory measurement of anticoagulation. Am J Clin Pathol. 2005;123(2):184-188.

8. Dorfman DM, Goonan EM, Boutilier MK, Jarolim P, Tanasijevica M, Goldhaber SZ.Point-of-care (POC) versus central laboratory instrumentation for monitoring oral anticoagulation. Vasc Med. 2005;10(1):23-27.

9. Boehlen F, Reber G, Moerloose P. Agreement of a new whole-blood PT/INR test using capillary samples with plasma INR determinations. Thromb Res. 2005;115(1-2):131-4.

Welcome to the $16^{\text {th }}$ ISPW!

Welcome to Lisboa!
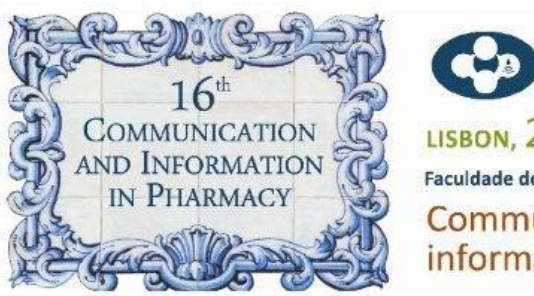

LISBON, 23rd $/ 26^{\text {th }}$ AUGUST 2010

Faculdade de Farmácia da Universidade de Lisboa

Communication and

information in pharmacy

This is a preliminary short announcement for the $16^{\text {th }}$ ISPW

Host Institution and Venue

Faculty of Pharmacy, University of Lisbon, Portugal

Dates

$23^{\text {rd }}$ to $26^{\text {th }}$ August 2010

Key note Speakers and further information soon to be announced at

www.ff.ul.pt/16ISPW

For any inquiries, please use the following email address: 161 SPW@ff.ul.pt

Hope to have you here in Summer 2010! 